\title{
The Hon. Sir HENRY ALFRED McCARDIE, Kt.
}

The recent death, under tragic circumstances, of this eminent judge deprives the English judicial bench of one of its best-known occupants.

Mr. Justice McCardie was especially distinguished for his interest in medico-legal questions. He presided at the trial of Rex $v$. Ronald True, and his summing-up in that case raised questions of great importance as regards the vexed topic of "criminal responsibility". Some years later, he presided at the second trial of Rex $v$. Thick. Both these cases were reported in the Journal of Mental Science.

There can be no doubt that Mr. Justice McCardie was a great judge. His summing-up in an important criminal trial was always a model of lucidity. He was invariably most courteous to medical witnesses. On many controverted matters, for example, that of abortion, he held strong views ; and he never hesitated to risk a temporary unpopularity by expressing his opinion publicly.

The deceased judge always took a keen interest in the Royal MedicoPsychological Association. He was Maudsley Lecturer in 1930, and his pronouncements on "Truth", especially as seen in a court of law, were given wide publicity at the time. Apart from his extensive knowledge of the law, he was an ardent scholar, and he had wide interests in the field of literature.

He was the recipient of the honorary degree of Doctor of Laws from the University of Birmingham. He was unmarried.

M. H. S. 